\title{
Which business starters experience limited access to bank funds?
}

Citation for published version (APA):

Letterie, W. A., \& Blumberg, B. F. (2002). Which business starters experience limited access to bank funds? METEOR, Maastricht University School of Business and Economics. METEOR Research Memorandum No. 030 https://doi.org/10.26481/umamet.2002030

Document status and date:

Published: 01/01/2002

DOI:

10.26481/umamet.2002030

Document Version:

Publisher's PDF, also known as Version of record

\section{Please check the document version of this publication:}

- A submitted manuscript is the version of the article upon submission and before peer-review. There can be important differences between the submitted version and the official published version of record.

People interested in the research are advised to contact the author for the final version of the publication, or visit the DOI to the publisher's website.

- The final author version and the galley proof are versions of the publication after peer review.

- The final published version features the final layout of the paper including the volume, issue and page numbers.

Link to publication

\footnotetext{
General rights rights.

- You may freely distribute the URL identifying the publication in the public portal. please follow below link for the End User Agreement:

www.umlib.nl/taverne-license

Take down policy

If you believe that this document breaches copyright please contact us at:

repository@maastrichtuniversity.nl

providing details and we will investigate your claim.
}

Copyright and moral rights for the publications made accessible in the public portal are retained by the authors and/or other copyright owners and it is a condition of accessing publications that users recognise and abide by the legal requirements associated with these

- Users may download and print one copy of any publication from the public portal for the purpose of private study or research.

- You may not further distribute the material or use it for any profit-making activity or commercial gain

If the publication is distributed under the terms of Article $25 \mathrm{fa}$ of the Dutch Copyright Act, indicated by the "Taverne" license above, 


\title{
Which business starters experience limited access to bank funds?
}

\author{
Boris Blumberg* \\ and \\ Wilko Letterie ${ }^{* *}$ \\ Fourth Version: October $18^{\text {th }}, 2002$
}

\begin{abstract}
:
In this paper we investigate which individuals face difficulties in raising funds from financial institutions when starting a business. We argue that banks are more likely to provide financial funds the more they are convinced that the loan is repaid timely and the business is likely to succeed. Thus, potential business founders can increase their chance to obtain a bank loan by committing themselves to repayment and their new business. Further, they can signal to the bank that they are good lenders. Our empirical analysis proceeds in two steps reflecting the supply and demand side of the market for business loans. First, we estimate the denial rate of banks and then we also look whether potential business founders differ in their likelihood to apply for credit. Our main findings are that home ownership, experience obtained in previous jobs, education, family composition, nationality, parental self-employment, multipleownership and income derived from previous occupation affect access to external financial resources. We argue that business plans and support obtained from an accountant are effective ways to signal credibility to a bank.
\end{abstract}

Keywords: self-employment, capital market imperfections

JEL codes: G20, J23

*Assistant Professor of Management Sciences, Maastricht University, Business Investment Research Center, P.O. Box 616, 6200 MD Maastricht, The Netherlands, b.blumberg@mw.unimaas.nl; ${ }^{* *}$ Associate Professor of Management Sciences, Maastricht University, Business Investment Research Center, Center of Strategy Studies, P.O. Box 616, 6200 MD Maastricht, The Netherlands, w.letterie@mw.unimaas.nl; We like to thank participants of the Scientific Council Meetings of BIRC and of the Q-seminar series. All errors remain our own as usual. The authors acknowledge the PIONIER program (grant number 400-10-041) of the Netherlands Foundation for Scientific Research (NWO) for financial support. 


\section{Introduction}

Banks hesitate to lend funds to businesses in general and small enterprises in particular. ${ }^{1}$ Ang (1991, 1992) discusses the extent of capital market imperfections in the context of small establishments and observes that in judging credit applications banks face several serious information problems. First, as usual the applicant's information concerning the prospects of the project is usually better than that of outsiders. Information asymmetries may be substantial in the context of small businesses because of the relatively high fixed cost of gathering information the bank incurs for a small transaction. Furthermore the smaller number of repeated transactions; the smaller incentives of outside analysts to collect information; and the fewer instruments available to small businesses to signal their credibility yield conditions under which serious information asymmetries prevail. Second, the quality of the data provided by small business owners for review by stakeholders like banks is often poor due to a lack of management experience or staff to produce useful information. Ang $(1991,1992)$ notes that an advantage of small businesses is that the managers are often the owners as well. This feature may resolve the manager versus ownership problem. However, he also argues that conflicts of interest between the owner and other stakeholders, like suppliers exercising monopoly power, may be more serious. For all these reasons it is not surprising that banks hesitate to provide loans to businesses and seek protection by requiring collateral. Therefore, any business owner seeking bank financing needs to overcome the hesitation and doubts of banks. This paper investigates how commitments and signals are means for a potential business founder to convince a bank providing a loan.

The motivation for this research stems from the fact that entrepreneurial activity is hampered by limited access to financial resources. The evidence of capital market imperfections in the 
context of starting businesses is widespread. For instance, Evans and Jovanovic (1989) report that personal wealth facilitates an individual's possibility to become self-employed. Likewise, the receipt of an inheritance or other windfall gains raises the probability of entering selfemployment (Holtz-Eakin et al., 1994a, 1994b ; Lindh and Ohlsson, 1996; Blanchflower and Oswald, 1998). Finally, Black et al. (1996) argue that supply of collateral due to home ownership enhances the formation of new firms. So far very little is known about the characteristics of individuals who would like to start a business, but are restricted in doing so because of limited access to external financial resources. This paper intends to provide some insight into this issue. In fact, we analyze data collected among 1163 individuals living in the Southern part of Limburg (The Netherlands) who considered becoming self-employed in 1998 and 1999. For starting their business 347 of them required additional external funds and applied for capital provided by a bank. The survey provides information about whether these individuals made an application at a bank and it indicates to which extent these applications have been granted. In addition it informs about education, work experience and social background of the potential business founders. An interesting feature of the data we consider is that it provides information about a number of commitments and signals an applicant may give to enhance the credibility of the project. In particular, we observe whether an applicant has written a business plan or has consulted an accountant when applying for credit. Since these two activities are costly commitments of own resources, they may reveal that the applicant's expectations about the profitability of the project are high. This idea is in line with insights obtained from the literature on signaling games, where in equilibrium costly messages reveal the type of the sender (Myers and Majluf, 1984; Gibbons, 1992). We investigate whether applications supported by these signals are more likely to be approved. 
The paper proceeds as follows. In section 1 a model is developed by which we can identify the characteristics of individuals who are more likely to face financial constraints. This model determines the probability that an individual is constrained in terms of receiving financial resources from a bank. In section 2 we provide an overview of the empirical and theoretical literature that is relevant to our subject. Section 3 describes the data we analyze. We estimate a logit model that relates the probability of experiencing financing constraints to a set of variables we observe. The results are depicted in section 4. In case loan applications are costly, some individuals may not apply because they fear this effort will be unsuccessful anyway. Such individuals might also be regarded as constrained. Therefore, we also present some results we obtain from estimating a logit model, which explains the probability that an individual applies for credit at a bank. This exercise provides some further insight into the characteristics of individuals who experience financial obstacles to start their own business. Finally, section 5 provides a conclusion.

\section{The identification of liquidity constrained individuals}

In order to determine which individuals are more likely to experience limited access to funds provided by financial institutions we adopt an approach developed by Jappelli (1990). He argues that to assess whether an individual is rationed one must take account of the demand and supply for capital. More formally, suppose that in the absence of any borrowing constraints $K^{*}$ denotes the optimal amount of capital the individual wants to invest if he or she becomes self-employed. The stock of non-human wealth is denoted by $A$. The parameter $D$ measures the amount of credit obtained. We define an individual to be liquidity constrained if

(1) $K^{*}-A>D$ 
This equation indicates that liquidity constraints appear if the individual's resources, $A$, are insufficient to purchase $K^{*}$ and if the banks are reluctant to lend money, i.e. when $D$ is small.

To proceed with this framework it would be desirable to derive $K^{*}$ from some optimization problem faced by the business founder. However, this requires the optimization of a dynamic model of factor demand. ${ }^{2}$ Usually these models are very complicated and it is often difficult and sometimes impossible to solve for the optimal amount of factor inputs (Hamermesh and Pfann, p. 1274, 1996). ${ }^{3}$ In our framework this observation implies that it is not straightforward to deliver a closed form solution for $K^{*}$. Therefore, we assume that the demand for funds, which is given by the difference between the desired stock of capital and non-human wealth, can be approximated by $K^{*}-A=X \alpha+\varepsilon$. The matrix $X$ contains variables like age, education, work experience, social background etc. ${ }^{4} \alpha$ represents a parameter vector and $\varepsilon$ is stochastic.

In the context of capital market imperfections, banks may be reluctant to lend money (Ang, 1991, 1992). Due to agency costs and asymmetric information the size of $D$ may be insufficient to cover $K^{*}-A$. Hence, for some individuals who intend to start a business equation (1) will hold. The supply of funds is given by the debt ceiling $D$, which is presumed to be a linear function of the same variables: $D=X \delta+v . \delta$ is a vector of parameters and the term $v$ is random. It follows that (1) can be restated as

(2) $\quad X \beta+\mu>0$ 
where $\beta=\alpha-\delta$ and $\mu=\varepsilon-v$. The expression $X \beta$ approximates the excess demand for capital from banks. We like to mention that in principle $\alpha$ and $\delta$ may contain zeroes, to account for the notion that some variables affect demand but not the supply of funds for instance. However, because of the reduced form nature of the above model it is not possible to identify $\alpha$ and $\delta$ separately. The dummy variable $Z$ indicates whether an individual is credit constrained or not. We assume that if he or she does not receive the full grant and hence experiences difficulties raising sufficient funds from banks to purchase the desired stock of capital, then $Z=1$ and $X \beta+\mu>0$. Otherwise $Z=0 .^{5}$ The stochastic nature of equation (2) allows us to derive the probability that an individual experiences credit constraints: $\operatorname{Pr}(Z=1)=F(X \beta)$ where $F$ is assumed to be the logistic distribution function.

\section{A closer inspection of credit denial and application}

\section{Commitments and signals as means to reduce information asymmetries and agency costs}

The vast majority of small firms and business start-ups relies on commercial banks for obtaining additional financial funds (see, e.g., Keasey \& Watson 1992). Equity financing is hardly a viable alternative, because the equity market for small firms is not well developed, most entrepreneurs lack the experience and expertise to obtain equity financing and raising equity is rather costly and therefore inefficient for smaller financing volumes. Although bank loans are the most widely used form of small and new business financing, the exchange relation between banks and their small business clients often suffers from market imperfections, such as agency costs and information asymmetry. Banks are unable to assess the credit risks of a venture well and the business starters' assessment of their ventures suffers from an 'optimistic' bias. Especially in markets where it is difficult to distinguish between good and bad credit risks, these capital market imperfections result in a supply shortage of 
financial funds. Some new ventures with positive net present value cannot attract the necessary financial funding, because banks ask for high risk premiums and ration credit (Stiglitz \& Weiss, 1981). Banks are more likely to approve a credit request at reasonable terms, if the bank is convinced that the business is likely to succeed or if the bank is able to collect the debt, even if the proposed venture fails. Credible commitments and signals on part of the business starter are mechanisms enhancing the chance to collect the debt and the bank's ability to assess the success chance of the venture. Thus, business starters can increase their possibilities to obtain the required financial funds by giving such credible commitments and signals (Avery et al. 1998).

Figure 1 shows how credible commitments and signals mitigate the bank's fear to invest in a venture with negative net present value and to loose the provided debt. In terms of our model introduced in section 1 , each cell of figure 1 refers to a broad category of explanatory variables collected in the matrix $X$. In the following, we will work out the cell entries of the figures starting with the upper left cell and proceeding clock-wise. Credible commitments guaranteeing the repayment of the debt even if the business fails are linked to collaterals underlying the loan. Such collaterals, i.e. the private wealth of a business starter as well as redeployable assets of the firm, like e.g. buildings and machinery, reduce the bank's exposure to loosing the debt (Keasey \& Watson 2000). Evidence in favor of this conjecture is provided by related studies, which show that the chance to obtain credit is significantly increased by collateral commitments, such as home ownership (Black et al., 1996) and investments in buildings and machinery (Levenson \& Willard 2000).

Next to collateral, the earning capacity of a business starter in a subsequent job, i.e. the job after the eventual failure of the business, is a signal to the bank, whether the business starter 
can meet his credit obligations even if the business fails. Young and highly educated business starters are more likely to have a high post-failure earning capacity than older and less educated people. The income that a business starter earned previously, is another indicator, which signals the earning capacity after an eventual failure.

*** Insert Figure 1 about here $* * *$

Although banks care about debt-repayment, their primary objective is to allocate their funds to successful ventures (see last row of figure 1), because they profit much more from a longterm relation with a new business that grows to an established firm (Storey 1993). Banks are seeking promising new business proposals, whose risks they can evaluate well. Thus, business starters need to convince banks that their proposals are promising and can be assessed well. The broad literature on successful business start-ups offers an insight on, which factors serve as a signal for new business success. Several studies show that the founder's career affects the success of the new business (Brüderl, Preisendorfer \& Ziegler 1992; Gimeno et al. 1997; van Praag 1996). Further, demographic characteristics and the social background of the business starter are related to success. Married persons are more likely to become successful entrepreneurs, because their spouses offer them additional financial and emotional support. Further, spouses often work as a relatively cheap and very reliable 'employee' in the new business or they hold a paid job, which eases the liquidity of the entrepreneur's household and allows re-investing more earnings into the business. ${ }^{6}$ Children require care, money, effort and time, which cannot be invested in the newly founded business. As a consequence, individuals who are responsible for children had and have little opportunities to spare resources for their business and are less likely to succeed. In the US, a number of studies have shown that access to bank financing is more difficult for ethnic minorities (Bates, 1991; Munell et al. 1996; 
Blanchflower et al., 1998; Cavalluzzo \& Cavalluzzo, 1998). Discrimination on ethnic background is one possible explanation for these results (Blanchflower et al., 1998). However, most studies on this issue observe that it is also possible that ethnic background is correlated with other characteristics, such as personal wealth, education, credit history etc., that banks consider relevant in the determination of the business success chances. This implies that if a researcher does not measure such variables satisfactorily, then ethnicity is likely to be a significant explanatory variable of bank decisions, because it takes account of the effects of omitted variables. Therefore, one should be cautious in the interpretation of the effects of ethnic background.

We also explore whether multiple ownership facilitates access to bank loans. On the one hand banks may be reluctant to provide financial support due to complex agency problems if more parties are involved in the financing of a business. Then coordination and agency problems are larger (Ang, 1991). On the other hand multiple ownership reveals that the business founder was able to convince others to invest in his business. This could be an important signal for the bank and reduces the uncertainty of the creditor. Furthermore, many individuals liable for the underlying loan reduce the bank's risk in case of bankruptcy. These observations indicate that it is difficult to predict a priori whether banks appreciate the presence of other parties, who already committed their resources to a new business venture. Hence, the empirical analysis has to resolve this issue.

The reluctance of banks to provide credit for business start-ups is also influenced by the difficulties to assess a new business. From the bank's perspective information provided by the entrepreneur is less reliable, because the entrepreneur has a self-interest in exaggerating the success chances of his business. Entrepreneurs can diminish this reluctance with 
commitments increasing the credibility of their credit application (Ang, 1991). Entrepreneurs can improve the decision basis of banks by providing more detailed and more reliable information by writing a business plan for instance. Especially if the financial plan of the venture is designed with the support of an accountant and if an accountant approves of it, banks may be more willing to grant a loan. The provision of such better information is costly for the entrepreneur and thus he has to commit own resources before a decision on the credit application has been taken. The fact that the entrepreneur incurs costs to convince the bank of the worthiness of the credit application with better and more reliable information should give the bank also more faith in the success potential of the business idea. The extent to which a business founder commits own resources to the venture also signals to the banks that they are investing in a serious business idea. Own investments are a credible commitment mitigating the principal agent conflict between stockholders and bondholders, because the more own money business starters invest, the less likely it is that they take on very risky investments. ${ }^{7}$

In general, we expect that the approval chance of credit application increases with the amount as well as the credibility of the commitments and signals an entrepreneur places to convince the bank that she or he is a reliable person pursuing a business idea with good success chances. Here, it should be noted that financing of new businesses can solely be based on the assessment of a person, the potential business founder, and a blueprint of an idea, since past financial records do not exist. Thus, characteristics of the entrepreneur will play an even more crucial role.

\section{Interplay between denial and application rates}

In the previous sections we provided arguments to explain the chance that a bank approves a credit application and focused on the supply side of the market for new business financing. 
However, business starters - even those with very promising business ideas - may not apply for credit because they expect their efforts to be unsuccessful anyway. Especially if the cost for a credit application is substantial and the probability of being rejected is high, it may be optimal not to apply. Therefore, our analysis of the financing denial is likely to be biased towards finding a too small incidence of being denied regarding a number of variables (cf. Blanchflower et al., 1998). One could solve this problem by estimating a model that takes into account the application process and the outcome of the application simultaneously. However, such a Heckman correction approach requires a variable that is correlated with the individual's decision to apply, but does not affect the bank's decision to approve the loan or not. Such variables are very rare and the dataset we use in our empirical part does not provide it. Therefore we follow the approach suggested by Cavalluzzo and Cavalluzo (1998) who estimate a sequential response model in which the application and denial decision are treated as if they were independent (see Maddala, p. 49, 1983). In fact this allows us to analyze the two decisions separately. Of course the independence assumption is a rough one. However, we make it since it facilitates us to get some additional and useful insights into the determinants of capital market restraints.

Like the denial decision, we estimate the application equation using a logit model and consider the same explanatory variables. This can be explained as follows. An individual bases his or her decision to apply on the chance of a successful application, the utility derived from receiving a loan and the cost of applying. In the previous section, we argued that the availability of collaterals and the perceived success chances of a business reduce the chance that a bank denies a loan request. Thus, business starters that can provide the required collateral are more likely to ask for a bank credit, because their higher chance of credit approval justifies incurring the costs associated with a credit application. In addition, potential 
entrepreneurs, who believe that they are able to repay a debt even if their business idea fails, are also more likely to apply for credit, because a failure of their business will not disrupt their personal finances critically for a long time. Likewise, higher perceived success chances will convince a potential entrepreneur to seriously pursue his business idea and to apply for bank financing. First, the higher success chance increases the chance that a credit proposal will be approved and thus the preparation costs for the proposal are more justified. Second, business with higher success chance have by definition a lower failure chance. Thus, the entrepreneur's risk to end up in personal financial distress in case of a business failure is lower. In our data set there are no variables measuring differences in application costs. Furthermore, we lack information about how financial funds obtained from banks affect a business founder's utility. Hence, we will consider the same explanatory variables for both the application and denial model.

\section{Research design: Used data and information}

The estimation of the model is based on a survey that has been conducted among individuals living in the Southern part of Limburg, a Dutch province. This dataset is based on computer assisted personal interviews (CAPI) with 1223 respondents, who intended to start a business in 1998 or 1999.994 of the respondents started a business while 229 refrained from their original idea to become an entrepreneur (see Blumberg \& Pfann 2002 for further information on the survey). Due to partial item non-response we work with a total sample of 1163 respondents to analyze the application rate. Our sample for the analysis of the denial rates is based on a sub-sample of those 347 respondents, who applied for credit at a bank. Approximately $30 \%$ of these applications were denied full approval. During the interviews, all respondents provided extensive information on their educational and occupational career, 
their social background, their spouse, available financial capital, the founding process and the started business.

In our theoretical part, we linked the application- and denial rates to the entrepreneurs' possibilities to give credible commitments and signals. Our data do not provide direct measurements of such commitments and signals. Rather, we use variables, which can serve as reliable indicators for our theoretical constructs. Figure 2 shows which indicators are used to measure the different commitments and signals (see appendix I for relevant descriptives of the used variables). The available collateral is measured with the dummy variable home ownership, which equals one, if the respondent possesses a house and zero otherwise. Higher post-failure earning capacities are positively related to the variables age, high education and previous income. Age is measured in years, high education is measured with a dummy variable, which takes the value one if the respondent has completed higher vocational training or university. Previous income is proxied by the last year income the respondent earned and included in our analyses with four dummy variables, each representing an income spread of $\mathrm{HFL}^{8} 25000$ with income below HFL 25000 as reference category. Several variables concerning the previous occupational career as well as the demographics of the potential business starter are used to assess the success chances of the business. The variables leadership, previous self-employment and job similarity reflect the occupational career of the respondent. The former two variables are dummy variables that take the value one if the respondent has gained leadership experience in former jobs and has previously been self-employed, respectively. They equal zero otherwise. The variable job similarity measures to what extent his tasks as a self-employed are similar to the ones he performed in his previous job based on the respondent's assessment. The demographics of the respondents are described by parental self-employment, 
married, children and foreign. All variables are dummy variables, which take the value one if the respondent's parents have ever been self-employed, the respondent is married, the respondent has children and the respondent is born abroad, respectively. They are equal to zero otherwise.

$$
\text { *** Insert figure } 2 \text { about here *** }
$$

Signals helping a bank to improve it's own assessment of a business proposal are measured with the variables business plan and accountant. A business plan provides the bank with additional information on the proposed venture and thereby enlarges the bank's information basis. Business and financial plans that are designed with the aid of an accountant, who has to comply with certain legal and professional standards, enrich the information basis of a bank, because they are less biased. Further, we use 'multiple ownership' as an indicator for another signal about the promising qualities of the new venture.

\section{Empirical analysis of denial and application chances}

\section{Chances of credit approval}

In this section we study which individuals are more likely to experience limited access to financial resources supplied by banks by estimating the model we presented in section two. In table 1 we depict the estimation results. It indicates under which circumstances a bank is more likely to deny an application. We find that denial is less likely to occur if the applicant owns a house. Credible commitments with respect to the recollection chances of a debt increase the chance that a bank grants a credit. Previous income, high education and age signal the chance 
to recollect the debt - even if the business fails - from later income streams of the respondent. The coefficients of the variables high education and previous income are all not significant. Thus, banks do not consider the post-failure earning capacity in their decision. The variables age and age squared are also not significant, suggesting that banks do not account for differences in life time horizons when deciding on a credit application.

\section{ABOUT HERE TABLE 1}

All other variables in table 1 refer to commitments and signals concerning the success chance of a new business venture. With respect to commitments, we note that if the applicant shows faith in this business idea by committing own resources, banks are more likely to approve a credit application. In this study we investigated the writing of a business plan and the consultation of an accountant and find that both commitments reduce the incidence of loan denial. Apparently, applicants show their credibility to banks employing these commitments. As a consequence such applications are subject to less uncertainty and the bank is more likely to grant the application. ${ }^{9}$ Signals related to the success chances of the business have mixed results. The significant effect of the variable job similarity suggests that banks also tend to appreciate whether an applicant has performed a job previously of which the tasks are similar to the tasks that need to be performed when being self-employed. The presence of such specific human capital seems to be valued positively by banks. Surprisingly, the two variables previously self-employed and parental self-employment, which are directly related to specific human capital in the form of entrepreneurial skills do not have an effect. The coefficient of previously self-employed is not significantly different from zero. Though our data do not indicate whether an individual operated a business that went bankrupt previously, this finding could be in line with the notion, that in Europe contrary to the US unsuccessful attempts to 
start a business are regarded as an indicator for missing entrepreneurial qualities and not as a valuable experience.

Applicants who were born abroad or who have children are less likely to receive a full grant. Since we do not measure personal wealth very well in our data, the findings regarding ethnic background and family composition might reflect differences in wealth. We argued before that the presence of children might measure the lower capacity of such households to accumulate wealth fast, because of a higher level of consumption. The presence of children may also reduce time and financial resources available to conduct the newly founded business in a decent way. Individuals born abroad may have had little opportunities to save some funds and acquire wealth. We like to stress again that we cannot conclude that banks discriminate by race due to lack of sufficient data. It appears that applicants who intend to remain the single owner of the establishment are more likely to face financing constraints. Banks are slightly more likely to refute their request for funds since they are less likely to be able to be refunded in case of bankruptcy if the owner remains single and because multiple-ownership may signal a higher degree of credibility of the application. Apparently our results indicate that banks do not care much about the increased complexity of the agency problem in case of multiple-ownership. By and large, our analysis shows that indicators related to commitments have the expected effects while the indicators describing different signals show mixed and ambiguous results.

\section{Estimates of application rates}

Since the act of acquiring a loan is costly some individuals may be reluctant to apply. Hence, the findings above are likely to relate to applicants who expect to be successful in receiving a loan. We now turn to the question: "Who applies?". We present results in table 2. In the 
previous section we found that home ownership, the presence of a business plan, the support of an accountant and having a business partner decrease the likelihood that a loan is being denied. In line with this finding table 2 reports that these four variables increase the likelihood that an individual applies for a loan. Apparently in these instances the lower probability of being denied increases the incentive to apply.

\section{ABOUT HERE TABLE 2}

Though job similarity, presence of children and being born abroad did affect the probability of loan denial, it appears that these features do not influence the individual's incentive to apply. This may indicate that the effect on the probability of denial of these variables is small. As a consequence these variables may hardly affect the individual's decisions to apply or not.

Finally, a number of variables affect the decision to apply, but do not influence the probability of being denied. In fact, we find that a higher degree of education, the presence of selfemployed parents, and higher levels of income in jobs occupied prior to the decision to become self-employed, increase the probability of a loan application. The selection effect seems rather strong regarding these variables. As a consequence, we observe that individuals not satisfying these features do not apply for a loan, which could explain why we do not find significant effects regarding these variables in the loan denial model. ${ }^{10}$

\section{Conclusion}

The question we address in this paper is: "Who experiences limited access to funds from banks when starting a business?" We have conducted our analysis in two distinct steps. First, 
we have estimated a model that determines which features determine whether an application is fully granted or not by a financial institution. Secondly, we have estimated a model that explains which individuals apply for a loan. It is important to undertake this empirical exercise as well since some individuals may not apply for a loan since they expect to be unsuccessful. If applying for a loan is rather costly they will abstain from undertaking this effort. Such persons should be regarded as financially constrained as well.

We argued that a bank's decision to approve or deny a credit application depends on commitments and signals by the potential entrepreneur showing the bank that the new venture's success is likely and repayment of the debt is highly probable. In line with Black et al. (1996) we find that home ownership is important to acquire access to external financial resources. They find that many potential entrepreneurs who are at least as able as many of those who actually enter self-employment are prevented from starting because of a lack of collateral. To be able to invest in activities people regard worthwhile for which they require a loan from a bank individuals should be stimulated to build up property, which may be collateralized. Obviously, this provides an argument in favor of government policies directed towards households investing in housing assets. The question whether mortgage interest payments need to remain deductible from income taxes receives a lot of attention in public media and the political debate. Our results and those of Black et al. (1996) provide a strong rationale for at least some type of subsidies on housing assets. Furthermore, the high importance of collaterals suggests that state sureties for very promising business ideas of less wealthy individuals can foster self-employment and mitigate imperfections of the financial market. Education and previous income do only affect the chance to apply for credit but not the chance of credit denial. This result leans for two interpretations. Either, banks communicate their borrowing policy efficiently to potential entrepreneurs and people with 
low (previous) earning capacity self-select and do not apply for a bank loan or banks fail to approach individuals with a lower education and a low income, although some of these individuals have promising business ideas.

Writing a business plan and the support of an accountant enhance the credibility of a loan application. Apparently, small financial commitments, i.e. the incurred costs for writing a business plan and hiring an accountant, convince banks. Empirical studies on the survival of new businesses show that work experience, previous self-employment and leadership experience are positively related to success (see, e.g., Brüderl, Preisendörfer \& Ziegler 1992; Gimeno e.a. 1997; van Praag 1996). Our analysis suggests that banks appreciate if a potential business founder has gained relevant similar experience in a paid job, but are reluctant to value previous self-employment. The presence of children and being born abroad lowers the probability of a full grant. We stress that we do not conclude that banks discriminate by race. Since our data lack sufficient information on personal wealth our control for ethnic background may reflect differences in financial assets. Individuals who intend to remain the sole owner of the establishment are more likely to experience difficulties in receiving a full grant. Therefore, to enhance one's prospects of receiving funds form financial institutions entrepreneurs should consider cooperating with a number of partners. By and large, our analysis showed that banks honor commitments of the potential entrepreneur, but are more doubtful about the credibility of signals on the repayment probability and the business success. 


\section{References}

Ang, J.S., 1991, Small Business Uniqueness and the Theory of Financial Management, The Journal of Small Business Finance, vol. 1, pp. 1-13.

Ang, J.S., 1992, On the Theory of Finance for Privately Held Firms, The Journal of Small Business Finance, vol. 1, pp. 185-203.

Avery, R.B., R.W. Bostic and K.A. Samolyk, 1998, The role of personal wealth in small business financing, Journal of Banking and Finance vol. 22, pp. 1019-1061.

Bates, T., 1991, Commercial Bank Financing of White- and Black-Owned Small Business Start-ups, Quarterly Review of Economics and Business, vol. 31, pp. 64-80.

Black, J., D. de Meza and D. Jeffreys, 1996, House Prices, The Supply of Collateral and the Entreprise Economy, The Economic Journal, vol. 106, pp. 60-75.

Blanchflower, D.G., P.B. Levine and D.J. Zimmerman, 1998, Discrimination in the Small Business Credit Market, NBER working paper series number 6840.

Blanchflower, D.G. and A.J. Oswald, 1998, What Makes an Entrepreneur? Journal of Labor Economics, vol. 16, pp. 26-60.

Blumberg, B.F. and G.A. Pfann, 2001, Self-employment and the uncertainty reduction of social capital, IZA Discussion Paper No. 303, mimeo: IZA / University of Bonn.

Blumberg, B.F. and G.A. Pfann, 2002, Zelfstandig ondernemer in Zuid Limburg [Entrepreneur in South Limburg], Maastricht: Datawyse.

Brüderl, J., P. Preisendörfer and R. Ziegler, 1992, Survival chances of newly founded business organizations, American Sociological Review vol. 57, pp. 227-242.

Carroll, G.R. and E. Mosakowski, 1987, The career dynamics of self-employed, Administrative Science Quarterly, vol. 32, pp. 570-589.

Cavalluzzo, K.S. and L.C. Cavalluzzo, 1998, Market Structure and Discrimination: The Case of Small Businesses, Journal of Money, Credit and Banking vol. 30. pp. 771-792.

Evans, D.S., and B. Jovanovic, 1989, An Estimated Model of Entrepreneurial Choice under Liquidity Constraints, Journal of Political Economy, vol. 97, pp. 808-827.

Gibbons, R., 1992, A Primer in Game Theory, Harvester Wheatsheaf.

Gimeno, J., T.B. Folta, A.C. Cooper and C.Y. Woo, 1997, Survival of the fittest? Entrepreneurial human capital and the persistence of underperforming firms, Administrative Science Quarterly vol. 42, pp. 750-783.

Hamermesh, D.S., and G.A. Pfann, 1996, Adjustment Costs in Factor Demand, Journal of Economic Literature, vol. 34, pp. 1264-1292. 
Harris, M., and A. Raviv, 1991, The Theory of Capital Structure, Journal of Finance, vol. 46, pp. 297-355.

Holtz-Eakin, Douglas, David Joulfaian and Harvey S. Rosen, 1994a, Entrepreneurial Decisions and Liquidity Constraints, RAND Journal of Economics, vol. 25, pp. 334-347.

Holtz-Eakin, D., D. Joulfaian and R.S. Harvey, 1994b, Entrepreneurial Decisions and Liquidity Constraints, Journal of Political Economy, vol. 102, pp. 53-75.

Hubbard, R.G., 1998, Capital Market Imperfections and Investment, Journal of Economic Literature, vol. 36, pp. 193-225.

Jappelli, T., 1990, Who is Credit Constrained in the US Economy, Journal of Political Economy, vol. 105, pp. 219-234.

Keasey, K. and R. Watson, 1993, Small Firm Management. Ownership, finance and performance, Blackwell: Oxford.

Keasey, K. and R. Watson, 2000, Interest rate premia on UK small firm bank borrowings. A research note, Journal of Business Finance \& Accounting vol. 27, pp. 247-259.

Levenson, A.R. and K.L. Willard, 2000, Do firms get the financing they want? Measuring credit rationing experienced by small businesses in the US, Small Business Economics, vol. 14, pp. 83-94.

Lindh, T., and H. Ohlsson, 1996, Self-Employment and Windfall Gains: Evidence from the Swedish Lottery, The Economic Journal, vol. 106, pp. 1515-1526.

Maddala, G.S., 1983, Limited Dependent and Qualitative Variables in Econometrics, Econometric Society Monographs. Cambridge University Press: Cambridge.

Munell, A.H., G.M.B. Tootell, L.E. Browne and J. McEneaney, 1996, Mortgage Lending in Boston: Interpreting HMDA Data, American Economic Review, vol. 86, pp. 25-53.

Myers, S.C., and N.S. Majluf, 1984, Corporate Financing and Investment Decisions when Firms have Information that Investors do not have, Journal of Financial Economics, vol. 13, pp. 187-221.

Praag, C.M van, 1996, Determinants of successful entrepreneurship, Thesis Publishers: Amsterdam.

Stiglitz, J. and A. Weiss, 1981, Credit rationing in the market with imperfect information, American Economic Review, vol. 73, pp. 393-409.

Storey, D.J., 1993, New firm growth and bank financing, Small Business Economics, vol. 6, pp. 139-150.

Taylor, M.P., 1996, Earnings, independence or unemployment. Why become self-employed?, Oxford Bulletin of Economics and Statistics, vol. 58, pp. 253-266. 
Figure 1: Possible commitments and signals of the entrepreneurs to mitigate bank's fears

\begin{tabular}{|l|l|l|}
\hline & \multicolumn{1}{|c|}{ Commitments } & \multicolumn{1}{|c|}{ Signal } \\
\hline Chance to recollect debt & $\bullet$ collaterals & $\bullet \begin{array}{l}\text { post-failure } \\
\text { capacity }\end{array}$ \\
\hline $\begin{array}{l}\text { Assessment of new business } \\
\text { success chance }\end{array}$ & $\bullet \begin{array}{l}\text { provision of costly and } \\
\text { reliable information } \\
\text { investment of own } \\
\text { resources }\end{array}$ & $\begin{array}{l}\bullet \text { founder's previous career } \\
\text { founder's demographics } \\
\text { third party investments in } \\
\text { business }\end{array}$ \\
\hline
\end{tabular}

Figure 2: $\quad$ Used indicators for the possible commitments and signals

\begin{tabular}{|c|c|c|}
\hline & Commitments & Signal \\
\hline Chance to recollect debt & - home ownership & $\begin{array}{ll}\text { - } & \text { previous income } \\
\text { - } & \text { high education } \\
\text { - } & \text { age }\end{array}$ \\
\hline $\begin{array}{l}\text { Assessment of new business } \\
\text { success chance }\end{array}$ & $\begin{array}{l}\text { - } \text { business plan } \\
\text { - advice from accountant }\end{array}$ & $\begin{array}{ll}\text { - } & \text { job similarity } \\
\text { - } & \text { previously self-employed } \\
\text { - } & \text { leadership experience } \\
\text { - } & \text { parental self-employment } \\
\text { - } & \text { married } \\
\text { - } & \text { children } \\
\text { - } & \text { foreign } \\
\text { - } & \text { single ownership } \\
\end{array}$ \\
\hline
\end{tabular}


Table 1. Determinants of Denial Rates

(Reported estimates are obtained from logit model, standard errors in parentheses)

\begin{tabular}{|c|c|c|c|}
\hline Home ownership & -1.01 & $(0.34)$ & $1 \%$ \\
\hline High education & 0.23 & $(0.32)$ & \\
\hline HFL $25000 \leq$ Income $<$ HFL 50000 & -0.22 & $(0.42)$ & \\
\hline HFL $50000 \leq$ Income $<$ HFL 75000 & -0.16 & $(0.44)$ & \\
\hline HFL $75000 \leq$ Income $<$ HFL 100000 & -0.35 & $(0.55)$ & \\
\hline HFL $100000 \leq$ Income & -0.66 & $(0.59)$ & \\
\hline Age & -0.07 & $(0.12)$ & \\
\hline Age2 & 0.00 & $(0.00)$ & \\
\hline Business plan & -0.82 & $(0.28)$ & $1 \%$ \\
\hline Accountant & -0.71 & $(0.33)$ & $5 \%$ \\
\hline Job similarity & -0.55 & $(0.27)$ & $5 \%$ \\
\hline Previously self-employed & 0.10 & $(0.34)$ & \\
\hline Leadership & 0.37 & $(0.29)$ & \\
\hline Parental self-employment & 0.02 & $(0.27)$ & \\
\hline Married & -0.36 & $(0.39)$ & \\
\hline Children & 0.74 & $(0.39)$ & $5 \%$ \\
\hline Foreign & 1.12 & $(0.52)$ & $5 \%$ \\
\hline Single ownership & 0.57 & $(0.31)$ & $10 \%$ \\
\hline $\mathrm{N}$ & 347 & & \\
\hline Pseudo R2 & 0.14 & & \\
\hline Chi2 & 58.3 & & \\
\hline Log likelihood & -178. & & \\
\hline
\end{tabular}

$1 \%, 5 \%$ and $10 \%$ indicate the 1,5 and 10 percent significance level or better. 
Table 2. Determinants of Application Rates

$\underline{\text { (Reported estimates are obtained from logit model, standard errors in parentheses) }}$

\begin{tabular}{|c|c|c|c|}
\hline Home ownership & 0.41 & $(0.19)$ & $5 \%$ \\
\hline High education & -0.29 & $(0.16)$ & $10 \%$ \\
\hline HFL $25000 \leq$ Income $<$ HFL 50000 & 0.53 & $(0.23)$ & $5 \%$ \\
\hline HFL $50000 \leq$ Income $<$ HFL 75000 & 0.39 & $(0.24)$ & $10 \%$ \\
\hline HFL $75000 \leq$ Income $<$ HFL 100000 & 0.61 & $(0.30)$ & $5 \%$ \\
\hline HFL $100000 \leq$ Income & 0.53 & $(0.31)$ & $10 \%$ \\
\hline Age & 0.02 & $(0.06)$ & \\
\hline Age2 & -0.00 & $(0.00)$ & \\
\hline Business plan & 1.10 & $(0.15)$ & $1 \%$ \\
\hline Accountant & 2.18 & $(0.24)$ & $1 \%$ \\
\hline Job similarity & 0.14 & $(0.15)$ & \\
\hline Previously self-employed & 0.22 & $(0.19)$ & \\
\hline Leadership & -0.02 & $(0.16)$ & \\
\hline Parental self-employment & 0.25 & $(0.15)$ & $10 \%$ \\
\hline Married & -0.03 & $(0.21)$ & \\
\hline Children & 0.14 & $(0.19)$ & \\
\hline Foreign & 0.37 & $(0.29)$ & \\
\hline Single ownership & -0.28 & $(0.16)$ & $10 \%$ \\
\hline $\mathrm{N}$ & 1163 & & \\
\hline Pseudo R2 & 0.17 & & \\
\hline Chi2 & 235.0 & & \\
\hline Log likelihood & -591.3 & & \\
\hline
\end{tabular}

$1 \%, 5 \%$ and $10 \%$ indicate the 1,5 and 10 percent significance level or better. 
Appendix I : Descriptive statistics for individuals:

Who applied for credit Who considered becoming self-employed

Denied ( $=1$ if bank denies full grant) $\quad 0.29$

Apply (=1 if respondent applies for loan) -- $\quad 0.30$

$\begin{array}{lll}\text { Home ownership } & 0.74 & 0.69\end{array}$

$\begin{array}{lll}\text { High education } & 0.34 & 0.38\end{array}$

$\begin{array}{lll}\text { Income }>\text { HFL } 25000 & 0.13 & 0.18\end{array}$

$\begin{array}{lll}\text { HFL } 25000 \leq \text { Income }<\text { HFL } 50000 & 0.32 & 0.29\end{array}$

HFL $50000 \leq$ Income $<$ HFL $75000 \quad 0.31 \quad 0.28$

HFL $75000 \leq$ Income $<$ HFL $100000 \quad 0.13 \quad 0.11$

$\begin{array}{lll}\text { HFL } 100000 \leq \text { Income } & 0.12 & 0.13\end{array}$

$\begin{array}{lll}\text { Age } & 37 & 38\end{array}$

$\begin{array}{lll}\text { Business plan } & 0.63 & 0.42\end{array}$

$\begin{array}{lll}\text { Accountant } & 0.27 & 0.10\end{array}$

$\begin{array}{lll}\text { Job similarity } & 0.50 & 0.45\end{array}$

$\begin{array}{lll}\text { Previously self-employed } & 0.21 & 0.20\end{array}$

$\begin{array}{lll}\text { Leadership } & 0.58 & 0.54\end{array}$

$\begin{array}{lll}\text { Parental self-employment } & 0.40 & 0.35\end{array}$

$\begin{array}{lll}\text { Married } & 0.79 & 0.77\end{array}$

$\begin{array}{lll}\text { Children } & 0.67 & 0.66\end{array}$

$\begin{array}{lll}\text { Foreign } & 0.06 & 0.06\end{array}$

$\begin{array}{lll}\text { Single ownership } & 0.68 & 0.75\end{array}$

$\begin{array}{lll}\text { Number of observations } & 347 & 1163\end{array}$

The numbers in the table represent the means of the corresponding variables. 
${ }^{1}$ Harris and Raviv (1991) and Hubbard (1998) provide excellent reviews of the literature on capital constraints due to agency problems and asymmetric information.

${ }^{2}$ See Evans and Jovanovic (1989) for a static optimization problem.

${ }^{3}$ In particular the structure of adjustment costs and type of stochastic shocks may complicate the optimization problem of an establishment substantially.

${ }^{4} K^{*}$ may be approximated by a linear quadratic Taylor expansion given some assumptions about which variables affect $K^{*}$. Therefore we also include the square of age in our estimations. This is the only non-categorical variable in our analysis.

5 This definition of being credit constrained is consistent with the approach taken by Cavalluzzo and Cavalluzzo (1998), who also consider whether firms were able to receive full funding for the loan or not.

6 Japelli (1991) finds that married couples are less likely to be financially constrained consumers.

${ }^{7}$ In signaling games, in equilibrium costly messages may reveal the type of the sender. See for instance Myers and Majluf (1984) and Gibbons (1992).

${ }^{8}$ HFL (Hollandse Florijn) was the Dutch national currency (Dutch Guilder) at the time of the survey. HFL 1 equals approximately Euro 0.45.

${ }^{9}$ Without reporting the precise estimates we like to note that our results regarding the other explanatory variables remain if we drop these two indicators.

${ }^{10}$ It may be argued that the decision to apply for a loan and the decision to write a business plan or to consult an accountant coincide to a large extent. This may cause some endogeneity problems. Without reporting the estimates we note that exclusion of the variables "business plan" and "accountant" does not affect our results besides those concerning the variable measuring job similarity. 